\title{
Principle of University General Education Curriculum
}

\author{
Huijuan ZHAO ${ }^{1, a}$, Yijing XU ${ }^{2, b}$ \\ ${ }^{1}$ General Education Center, Beijing Normal University Zhuhai Campus, China \\ ${ }^{2}$ General Education Center, Beijing Normal University Zhuhai Campus, China \\ a bnuzhj2008@sina.com, b845443202@qq.com
}

Keywords: General teaching; General education curriculum; Principle of curriculum.

\begin{abstract}
This paper first describes the necessary about the courses, " Prediction Study of Accounting" and "Big data processing and data mining", opening in colleges. Secondly tells the story about the similarity and the differences of the teaching content of two courses, and the reason to put them in professional courses and general course. Finally, talk about the principle of courses setting in general courses and the experience engaged in managing the courses arrangement in the universities for the last 10 years.
\end{abstract}

\section{Introduction}

The technology, skills, majors or the developing progress of subjects, cannot live without the development and needs in the social society. Those technology, skills, profession, or disciplines that cannot adapt to or keep up with the times, it makes sense to see them gradually decline and even die. Looking back on the history of accounting, looking to the future of accounting work, accounting should implement the scientific outlook on development, conscientiously perform our duties, strengthen the ability construction, reform and innovation, down-to-earth work, for the enterprise development strategy and the national economic construction service, makes our country's accounting standards heading towards the international accounting standards, contributing to promote the harmonious development of world economy, is each of our accounting workers, especially the education workers in colleges and universities must bear an important responsibility. College education workers also shoulder the theory research and higher education popularization to the responsibilities of the job. Theory research should adapt to the development of the society, the spread of education should be effective and powerful. Beijing normal university Zhuhai Campus these years opened "Prediction Study of Accounting" and "Big data processing and data mining" courses, see these two courses as an example, this article will talk about the basic principles opening courses in the universities and the courses arrangement.

\section{The situation of setting Accounting courses and other similar majors}

Major in accountancy. Major introduction: "Major in accountancy is based on accounting, auditing, financial management of the basic theory of applied disciplines, with the basic theory of economics, management and knowledge as the foundation, mainly study the basic theory and basic skills of financial accounting, capital operation, assets restructuring, merger aspects of professional knowledge and international accounting practice, meanwhile attach importance to the cultivation of practice ability of students, focus on the practice, through the basic training in the simulation chamber and accounting computerization lab, training their ability to analyze and solve practical problems of accounting basic and comprehensive ability, and at the same time pay attention to strengthen students' 
financial management, auditing, law, tax law knowledge learning, for students after take the certified public accountant examination to lay a solid professional foundation."

Major in accounting. Major introduction: accounting is a study in how to confirm the income and the assets of an enterprise within the operating cycle. In addition to prepare the financial statements and the trading records of the enterprise, more important for an accountant to do is to be able to participate in the combination between enterprises, quality management, the using of the information technology in financial aspect, tax strategy and many enterprise management activities, the area of accounting expertise covering a wide range, including authentication, auditing, taxation, corporate accounting, management accounting, financial management, bankruptcy and liquidation, forensic accounting, budgeting, business consulting and so on.

The accounting major in colleges and universities. Professional profile: university accounting major is a branch of accounting. Training target: This major focus on training those people who adapts to the needs of the modern market economy, has the humanistic spirit, scientific literacy and honest quality, has the knowledge and ability in accounting, management and economic, be familiar with relevant legal policy, capable of doing works which is related to accounting, auditing and financial management in profit and nonprofit institutions, as in practical high quality talents with high comprehensive quality, strong ability of applied .

\section{The common problems that college accounting and similar profession are facing}

In present, most domestic colleges and universities have divided the university curriculum into "general class" and "professional (including professional base) class". And can be subdivided into: general compulsory courses, general course, professional required courses, professional limit course, and professional course. As well as the practice teaching link, which includes the course practice, graduation practice and graduation thesis, etc.. Because each major has different research direction and the employment demand, naturally it will have different specialized compulsory courses and professional limit (optional).

The problem is that our higher education (perform in every link of operation and implementation of teaching in colleges and universities) whether to achieve the scheduled training goal.

The social reality. For a long time, accounting is one of the most popular major in college admissions, for both students and parents, accounting is synonymous with stability and money, and the surface of high employment rate, also seems to confirm this idea. But for professional college graduates who is studying accounting, whether it's just as what they have been marketing, which is they never have to worry about unemployment and downsizing, with a skill in hand, they don't have to be worried anywhere? The fact is that the vast majority of graduates can only be engaged in some of the most basic cashier, accounting, and documentary positions. And four optimal international accountant firms are even orientating in non-financing students who is with top-notch comprehensive quality, aimed at more conducive to a comprehensive vocational training.... Whether this reflects that in the ever-changing business evolution, our education has lag behind the demand of the society. More brutal reality is that the present is not only newly graduated students, even old accountants who is in the traditional accounting industry for many years have also felt the unprecedented career crisis, and the cause of all this is, the whole China's accounting profession is currently integrating with the world, accounting has entered the stage of the high speed evolution, financial management has increased from the original functional department into an enterprise's' core strategy department, it directly affects the survival and development of an enterprise. In the past, the requirements an enterprise had for accounting was only just accuracy and legal financial information accounting and report ; Now, in the evolution and advance of big data technology reform, the pursuit of an enterprise for accounting information, has gone up to the effective support of business development and management improvement. 
The requirements of national level. On October 27, 2014, national ministry of finance issued the "accounting system of the ministry of finance on comprehensively advancing management guidance to the construction of" account in this file. How to implement the "leading indicators which is issued by this document: establishing the management accounting system which is adapted to China's socialist market economic system. Strive for cultivating a number of management accounting personnel throughout the country within three to five years; strive to through the efforts of 5-10 years or so, management accounting theory system with Chinese characteristics will basically be in place, the basic management accounting guidance system is built, management accounting personnel significantly strengthened, management accounting information level increased significantly, management accounting advisory services market prosperity, the management accounting in China is close to or reached the world advanced level.", high education institutions must look ahead and make your own contribution.

\section{The importance of the curriculum of the teaching reform in colleges and universities}

To complete the task, it is very important to introduce the latest theory and knowledge, adopt teaching model which is emphasize on practical things. And the new curriculum setting and the selection of new materials, especially the more practical teaching reform in colleges and universities mission today.

"Accounting predict learning" and "Big data processing and data mining" course, as for whether it can be set in universities class, or to see whether the content of the course is appropriate, and to achieve the goal of what it is.

"Accounting predict learning" teaching content, course target, teaching plan, and to develop a target. This course USES the teaching material is at the end of 2013, huazhong university of science and technology press published "the accounting forecasting - tradition, innovation and practice" (Zheng Yong).The book "in the system after reviewed the traditional accounting theory, has introduced that information technology and computer technology is not urgent environment accounting theory and methods, especially the grey forecasting theory, the new progress in the ARIMA model and so on in the accounting, the main academic ideas and research results, and the old and the new theory is applied to the price, sales, cost, profit, cash flow and the predict of other financial statements project at the same time, and give the accuracy of the prediction measurements". After the relevant trade-offs, the undergraduate teaching effect is also very good.

"Big data of processing and data mining" teaching content, curriculum objectives, teaching plan and training object. The course material is the "Depth understanding of big data - big data processing and programming practice" (Editor Huang Yihua, deputy editor Miao Kaixiang). Reference books to the students are recommended as follows: "Hadoop application development technology solution"(Editor Liu Gang) and " Actual combat big data" edited by Li Qian and Bao Liang. The teaching goal of the course is, the students a basic understanding of the big data in the basic framework in the enterprises application, the preliminary master the methods and steps for the "enterprise data system deployment and installation", for future employment after the actual work to lay a necessary foundation. This course, the ability to improve students' self-learning ability, analysis of problem areas to solve the problem is also a positive way.

From this, we can get the following conclusions: "Their origin is different, the research method is approximate", "Their essential basis of the environment is the same, the prediction of the theory is completely different, the scope of application is different", "Both are based on the basis of modern statistics, but the research directions and methods of the two are different.", "They all have many research results, but that are belong to different application category".

Based on the above analysis, the "Accounting Forecasting Science" as a "professional elective course" for the university finance and economics and management. "Big Data Processing and Data 
Mining" can be as "information university professional" professional elective course, or be set as a General education course.

In order to faster promotion of large data processing technology, adapt to the actual situation of the current society is in urgent need of the talent, since 2015, Beijing Normal University Zhuhai Campus, already set "Big Data Processing and Data Mining" as a General education course.

\section{Summary}

Colleges and universities set up courses. It is an important part of the education reform, it is also our today to achieve our aim of university education and embody the important step of teaching achievement, should cause the attention of the relevant departments.

\section{References}

[1] Information on http://baike.baidu.com/view/146411.htm

[2] Information on http://baike.baidu.com/view/1808005.htm

[3] Information on http://baike.baidu.com/view/10770757.htm

[4] Information on http://www.kuaiji.com/news/1945656

[5] Jianhua Zhang, Zhe Zhang, Zhen Ge, General Education and Internet, Advances in Education Research/Volume 22/ p.68

[6] Zhe Zhang, Jianhua Zhang, Zhen Ge, Comparison of Chinese and German Higher Education, Advances in Education Research/ Volume 22/ p.81

[7] Jianhua Zhang, Zhen Ge, General Education and Practice in University, Advances in Education Research/ Volume 4/ p.158 